\title{
REGE (Recycle Vegetable Waste): Pemberdayaan Limbah Sayur Menjadi Pupuk Organik Padat dan Cair Ramah Lingkungan di Pasar Koto Baru
}

\author{
REGE (Recycle Vegetable Waste): Empowerment of Vegetable Waste into Environmentally \\ Friendly Solid and Liquid Organic Fertilizer at Koto Baru Market
}

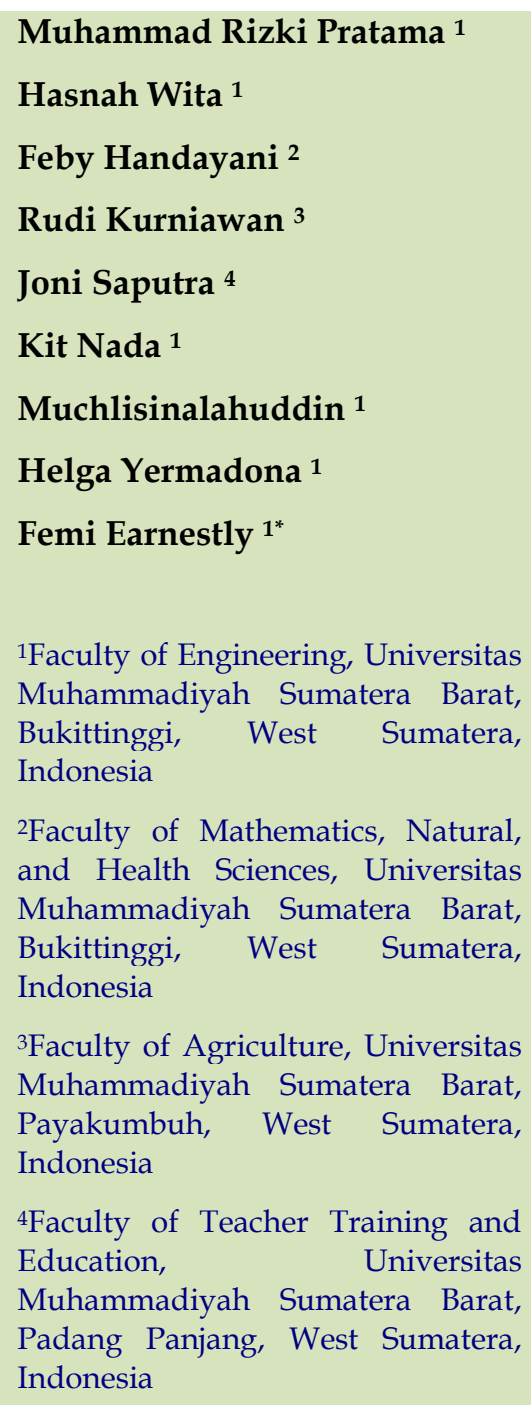

email: femiumsb@gmail.com

\section{Kata Kunci}

Jorong Subarang

Kompos

Sampah organik

Keywords:

Jorong Subarang

Compost

Organic waste

Received: April 2021

Accepted: October 2021

Published: January 2022

\begin{abstract}
Abstrak
Pupuk kompos memiliki keunggulan yaitu dapat memperbaiki sifat fisik tanah, sifat kimia tanah dan sifat biologi tanah. Hal ini dikarenakan karakteristik yang dimilikinya antara lain mengandung unsur hara dalam jenis dan jumlah bervariasi tergantung bahan asal, menyediakan unsur hara secara lambat (slow release) dan dalam jumlah terbatas, serta mempunyai fungsi utama memperbaiki kesuburan dan kesehatan tanah. Tumpukan sampah organik pasar Koto Baru memberikan dampak langsung terhadap lingkungan masyarakat Koto Baru. Program pengabdian bagi masyarakat ini mempunyai tujuan untuk meningkatkan pengetahuan dan keterampilan masyarakat sasaran tentang pengolahan limbah sayur pasar Koto Baru menjadi pupuk organik padat dan cair ramah lingkungan. Masyarakat yang menjadi sasaran pada kegiatan ini adalah Ibu-Ibu PKK Jorong Subarang Nagari Koto Baru pada khususnya dan masyarakat sepenulis Jorong Subarang Nagari Koto Baru. Metode yang digunakan dalam melakukan pengabdian ini adalah sosialisasi tentang pengolahan limbah sayur pasar Koto Baru menjadi pupuk organik padat dan cair ramah lingkungan, pembagian buku panduan praktek perakitan alat pembuatan pupuk organik padat dan cair dari limbah sayur, melakukan penyebaran kuisioner sebelum dilakukan sosialisasi secara online. Kegiatan ini memberikan dampak positif kepada Ibu-Ibu PKK ini antara lain memberikan pengetahuan ibu-ibu PKK tentang pemanfaatan limbah sayur organik pasar Koto Baru menjadi POP dan POC ramah lingkungan, tersebarnya informasi tentang pemanfaatan limbah sayur pasar Koto Baru menjadi pupuk organik padat dan cair ramah lingkungan di Jorong Subarang Nagari Koto Baru Kabupaten Tanah Datar.
\end{abstract}
Abstract
Compost has some advantages, improving soil physical properties, chemical properties, and biological properties. It happens because its characteristics contain nutrients in varying types and amounts depending on the original material, provide nutrients slowly (slow release) and in limited quantities, and have the main function of improving soil fertility and health. The pile of organic waste from the Koto Baru market directly impacts the environment to their community. This Community Service Program aims to increase the knowledge and skills of target communities about processing vegetable waste from the Koto Baru market into the solid and liquid-friendly environment of organic fertilizers. The target people of this activity were PKK Jorong Subarang Nagari Koto Baru women in particular and people who wrote Jorong Subarang Nagari Koto Baru. The methods used in this service were socialization of the processing of vegetable waste from the Koto Baru market into the solid and liquid-solid and liquid friendly environment of organic fertilizers, distribution of practical manuals for assembling tools for making solid and liquid organic fertilizer from vegetable waste, distributing initial questionnaires to online socialization. This activity had positive impacts on these PKK women, including providing knowledge of PKK women about the use of organic vegetable waste from the Koto Baru market to become a POP friendly environment and $P O C$, the dissemination of information on the use of vegetable waste from the Koto Baru market became a solid and liquid friendly environmental of organic fertilizer in Jorong Subarang Nagari Koto Baru, Tanah Datar Regency. 


\section{PENDAHULUAN}

Kompos adalah pupuk yang berasal dari proses pelapukan bahan-bahan yang berupa sisa sayuran, sampah organik dan lain-lain (Indriyanti et al., 2015). Pupuk kompos memiliki keunggulan yaitu dapat memperbaiki sifat fisik, kimia dan biologi tanah (Bachtiar \& Ahmad, 2019). Hal ini dikarenakan karakteristik yang dimilikinya antara lain mengandung unsur hara dalam jenis dan jumlah bervariasi tergantung bahan asal, menyediakan unsur hara secara lambat (slow release) dan dalam jumlah terbatas, serta mempunyai fungsi utama memperbaiki kesuburan dan kesehatan tanah (Anastasia et al., 2014).

Jika dilihat dari segi ekonomi sampah organik pasar tersebut masih memiliki nilai ekonomis apabila dilakukan pengolahan lebih lanjut seperti dibuat pupuk kompos, karena sampah organik tersebut masih mengandung kadar air yang tinggi serta mengandung bahan-bahan organik berupa karbohidrat, protein, dan lemak (Rachman et al., 2021). Sampah organik (limbah sayuran) pada dasarnya dapat digunakan menjadi pupuk organik padat (kompos; POP) dan pupuk organik cair (POC) dimana pupuk ini merupakan hasil fermentasi bahan organik limbah sayuran yang memiliki kandungan unsur hara lebih dari satu unsur (Natsi et al., 2016; Nur et al., 2016).

Mitra yang mengalami permasalahan terhadap kondisi lingkungan sekitar pasar Koto Baru adalah masyarakat yang tinggal disekitar pasar tersebut. Masyarakat di sekitar pasar Koto Baru mengalami beberapa keluhan terhadap kondisi lingkungan yang tercemar. Salah seorang warga masyarakat yang tinggal di sekitar pasar Koto Baru mengungkapkan beberapa masalah diantaranya bau yang tidak sedap yang disebabkan dari tumpukan sayur yang membusuk (Muslimah, 2015), dan pencemaran lingkungan dan berkurangnya keindahan sekitar pasar karena pasar Koto Baru merupakan jalan lintas utama (Ghufron et al., 2017). Dengan masalah kondisi lingkungan masyarakat Koto Baru tersebut membuat kami terinspirasi untuk melakukan pengabdian serta membagi ilmu pengetahuan tentang pemanfaatan dan pengolahan limbah sayur yang dapat menghasilkan POC dan POP.

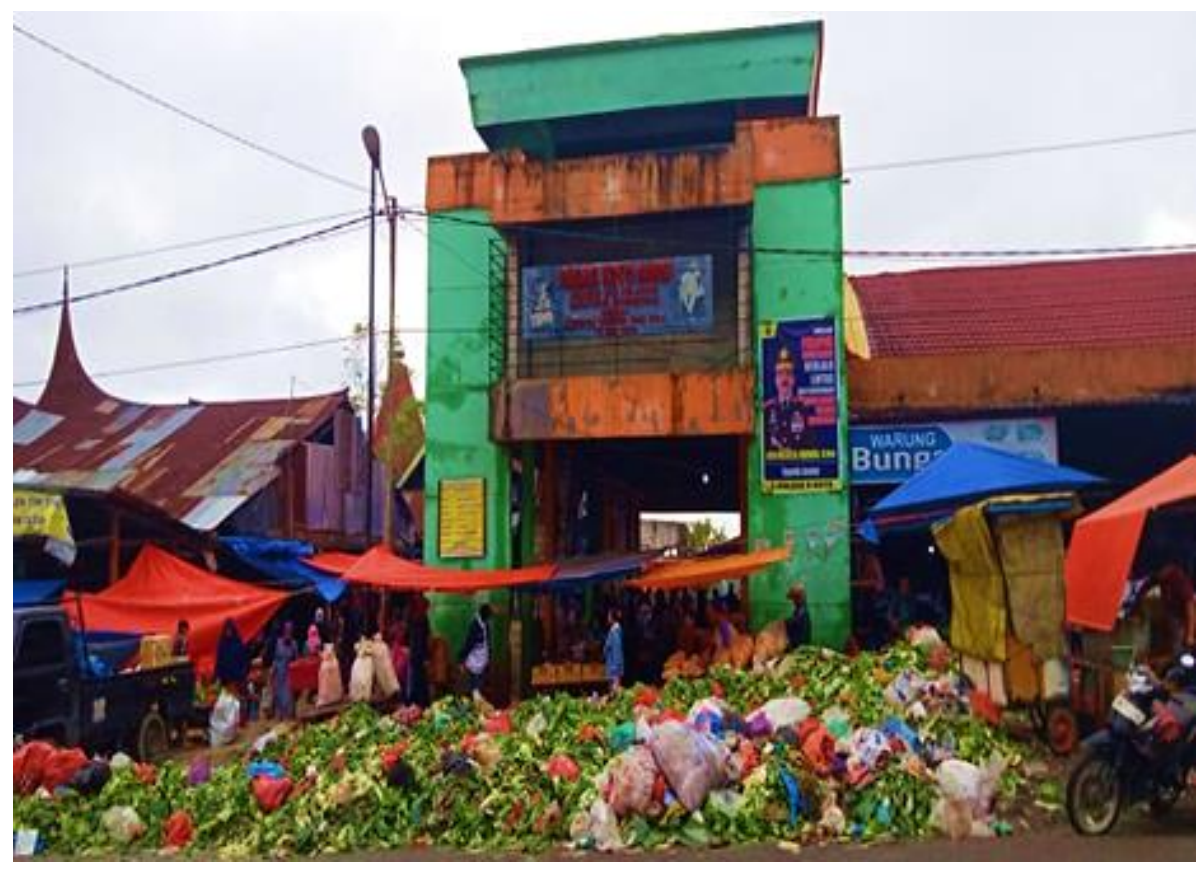

Gambar 1. Limbah sayur pasar Koto Baru

Terinsipirasi dari masalah limbah sayur yang ada di pasar Koto Baru ini, dan data dari grafik diatas, kami mempunyai ide memberikan tambahan pengetahuan berupa pemberdayaan limbah sayur pasar Koto Baru kepada masyarakat jorong Subarang, mengingat bahwa limbah sayur pasar Koto Baru ini sangat mengganggu aktifitas, dikarenakan itu kami ingin menerapkan teknologi pembuatan alat dan pemberdayaan limbah sayur pasar Koto Baru menjadi POC dan POP, masyarakat dapat memanfaatkan limbah agar lingkungan tidak tercemar dan terbuang begitu saja (Himawan et al., 2018). 
Pupuk organik cair adalah jenis pupuk yang berbentuk cair tidak padat mudah sekali larut pada tanah dan membawa unsur hara penting untuk pertumbuhan tanaman (Nur et al., 2016). Pupuk organik cair mempunyai banyak kelebihan diantaranya pupuk tersebut mengandung zat tertentu seperti mikroorganisme jarang terdapat dalam POP dalam bentuk kering (Mokodompis et al., 2018; Roidah, 2013).

\section{METODE}

Lokasi pengabdian adalah Jorong Subarang Nagari Koto Baru, Kecamatan X Koto Kabupaten Tanah Datar, Provinsi Sumatera Barat pada tanggal 21 September 2020. Alat yang digunakan untuk membuat POP dan POC yaitu drum $220 \mathrm{~L}$ dan $35 \mathrm{~L}$, pipa paralon 3 inchi, stok kran, selang, plat plastik, ember $20 \mathrm{~L}$, limbah sayur, promol, dan EM4. Tahapan metode pelaksanaan yang dilakukan untuk pengabdian kepada masyarakat di Jorong Subarang Nagari Koto Baru, Kecamatan X Koto Kabupaten Tanah Datar dimulai dengan sosialisasi. Pada tahap ini disosialisasikan pengetahuan tentang POP dan POC ramah lingkungan secara online melalui media WhatsApp, kegunaan POP dan POC, asal terbentuknya POP dan POC, penggunaan limbah sayur untuk penghasil POC dan POP. Sebelum sosialisasi, para panitia beserta pemateri memberikan kuisional awal pada peserta untuk mengetahui tingkat pengetahuan ibu-ibu PKK tentang limbah sayur, POC dan POP. Tahap berikutnya adalah menjelaskan desain komponen pembuatan alat POC, cara perakitan alat, dan fungsi bagian dari komponen alat tersebut, dan memberikan buku panduan kepada ibu-ibu PKK untuk memudahkan ibu ibu PKK dalam pembuatan alat POC dan POP.

Metode pelaksanaan pembuatan alat pembuatan POC terutama limbah sayur adalah mempersiapkan alat dan bahan, memilih sampah organik padat yaitu sayuran sebanyak $20 \mathrm{~kg}$, memotong limbah yang berukuran besar, Menyiapkan larutan media yang terdiri dari $2 \mathrm{LEM}_{4}$ dan dicampurkan dengan air sebanyak $10 \mathrm{~L}$ dan gula merah 2 ons, Setelah dipotong, sampah dimasukkan dalam karung dan dipadatkan lalu diikat, dimasukkan ke dalam ember, lalu dimasukkan karung yang berisi limbah kedalam ember hingga terendam seluruhnya. Batu diberikan diatas karung sebagai beban agar tidak mengapung. Wadah kemudian ditutup rapat hingga udara tidak dapat masuk, dan disimpan selama 7-10 hari ditempat teduh dan terhindar dari sinar matahari langsung, Setelah proses fermentasi selesai, karung diangkat dan dipisahkan dari larutan media, POC sudah dapat digunakan. Setelah melakukan sosialisasi secara online dan pembagian buku panduan praktek perakitan alat pembuatan POP dan POC dari limbah sayur dibagikan kuisioner akhir kepada ibu-ibu PKK.

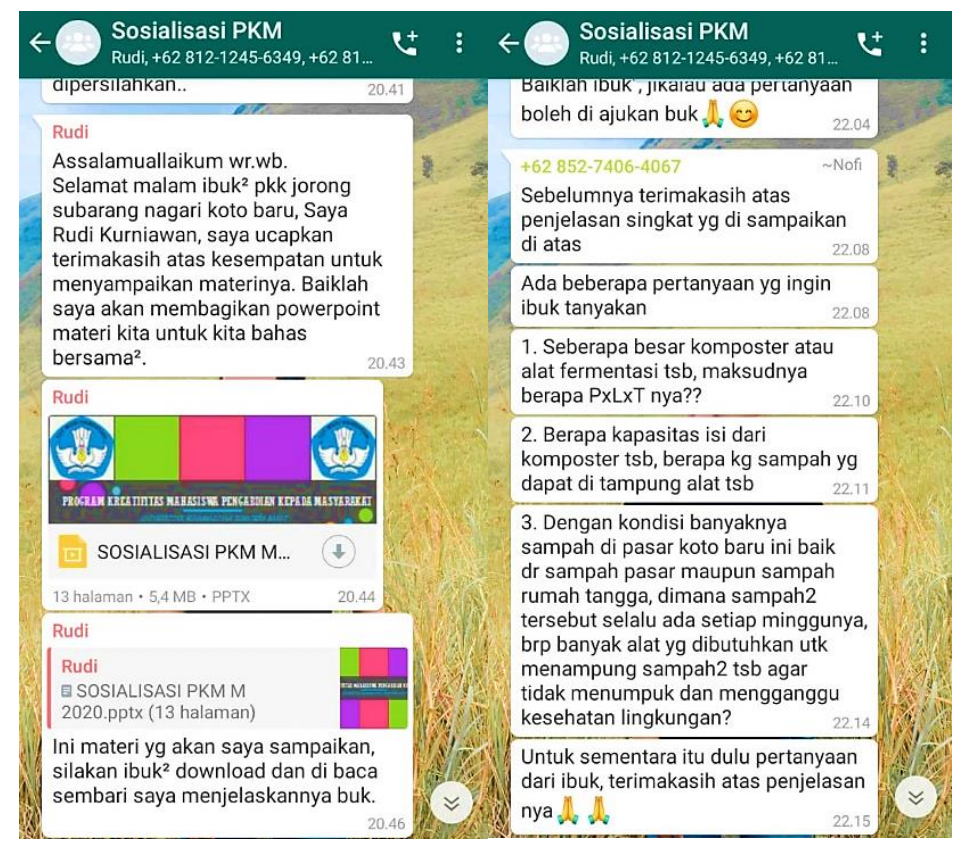

a

b

Gambar 2. Sosialisasi online (a) dan sesi tanya jawab dengan mitra (b) 


\section{HASIL DAN PEMBAHASAN}

Sosialisasi dilaksanakan secara online berhubung Covid-19 melalui grup WhatsApp pada tanggal 21 September 2020 pukul 20.30 WIB yang diikuti sebanyak 15 orang ibu-ibu PKK. Sebelum dilaksanakan sosialisasi penulis membagikan kuisioner awal kepada ibu-ibu PKK secara online berupa pertanyaan sebanyak 15 soal, untuk mengetahui tingkat pengetahuan masyarakat terhadap pemanfaatan limbah sayur organik pasar Koto Baru menjadi kompos. Grafik kuisioner awal dapat dilihat pada Gambar 3.

\section{Apakah masyarakat Koto Baru mengetahui tentang manfaat limbah sayur organik..? \\ 16 tanggapan}

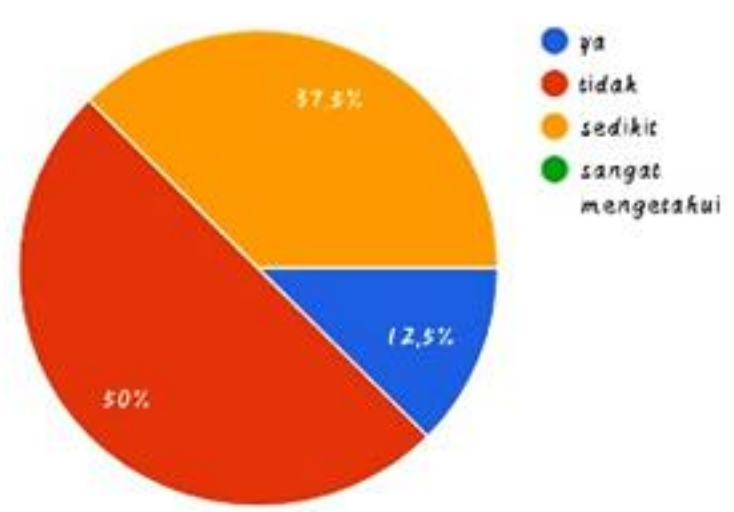

Gambar 3. Grafik pengetahuan manfaat limbah organik

Dari Gambar 3 dapat dilihat bahwa berdasarkan pertanyaan yang diberikan didapatkan (37,5\%) sedikit mengetahui tentang manfaat limbah sayur organik, (12,5\%) mengetahui tentang manfaat limbah sayur organik, (50\%) tidak mengetahui tentang manfaat limbah sayur organik.

\section{Berikut dampak negatif tumpukan limbah sayur bagi masyarakat, terutama..? \\ 16 tanggapan}

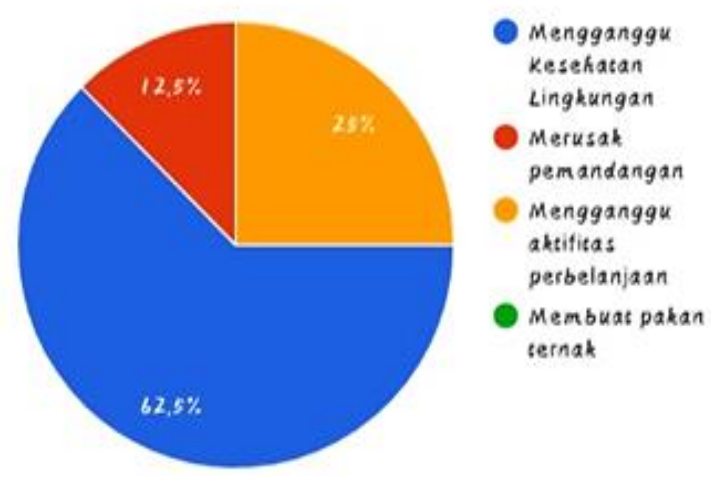

Gambar 4. Grafik pengetahuan dampak negatif limbah 
Dari Gambar 4 dapat dilihat bahwa berdasarkan pertanyaan yang diberikan didapatkan (25\%) dampak negatif limbah bagi masyarakat mengganggu aktifitas, $(12,5 \%)$ dampak negatif limbah merusak pemandangan, $(62,5 \%)$ dampaknegatif limbah bagi masyarakat mengganggu kesehatan lingkungan.

\section{Seberapa paham anda dengan teori pemanfaatan limbah sayur menjadi pupuk organik?}

\section{6 responses}

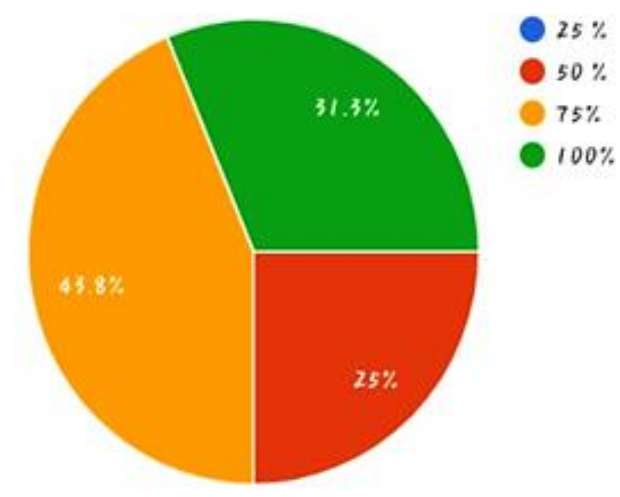

Gambar 5. Grafik pengetahuan penggunaan limbah sayur

Dari Gambar 5 dapat dilihat bahwa (43,8\%) masyarakat Koto Baru memahami pengetahuan limbah sayur menjadi pupuk organik $75 \%$, (31,3\%) memahami pengetahuan limbah sayur 100\% dan (23\%) memahami pengetahuan $50 \%$.

\section{Bagaimana cara mengatasi limbah sayur yang menumpuk di pasar Koto Baru?}

\section{6 tanggapan}

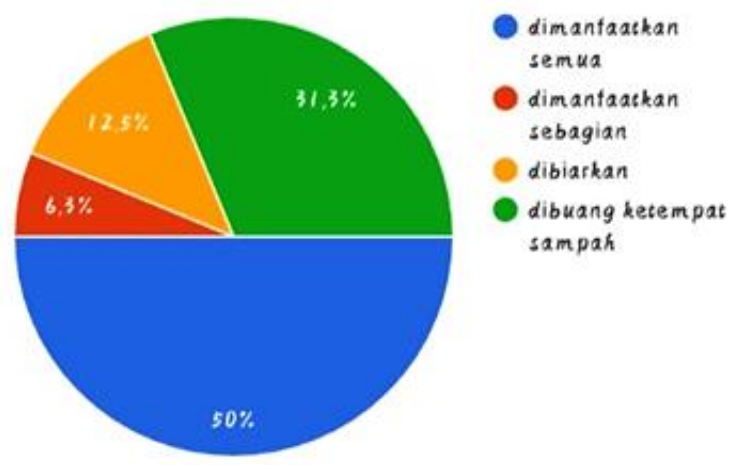

Gambar 6. Grafik pengetahuan mengatasi limbah sayur

Dari Gambar 6 dapat dilihat bahwa (6,3\%) cara mengatasi limbah sayur yang menumpuk dengan cara dimanfaatkan sebagian, (12,5\%) masyarakat Koto Baru mengatasi limbah sayur yang menumpuk dibiarkan saja, (31,3\%) masyarakat Koto Baru mengatasi limbah sayur dengan cara dibuang ke tempat sampah, dan (50\%) masyarakat Koto Baru mengatasi limbah sayur dengan cara dimanfaatkan semuanya. 


\section{Apakah tumpukan limbah sayur di \\ Pasar Koto Baru mengganggu \\ kenyamanan transaksi dipasar?}

16 tanggapan

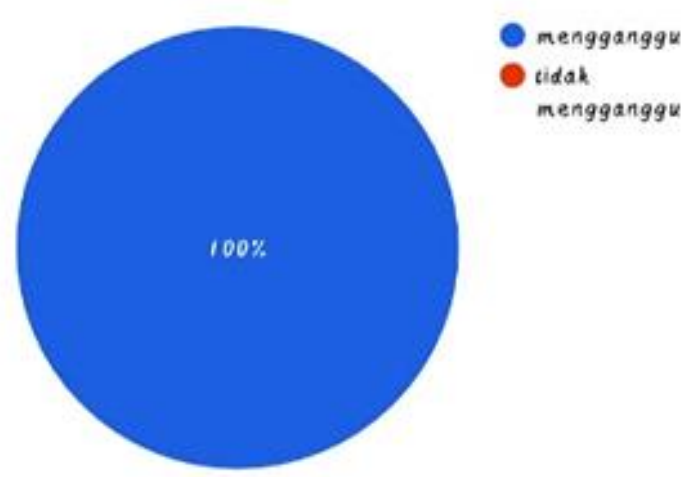

Gambar 7. Grafik pengetahuan akibat tumpukan limbah

Dari Gambar 7 dapat dilihat bahwa (100\%) masyarakat Koto Baru sangat terganggu kenyamanan dalam transaksi di pasar akibat tumpukan limbah sayur tersebut.

\section{Proses pelapukan bahan-bahan \\ organik berupa sayuran, disebut...?}

\section{6 tanggapan}

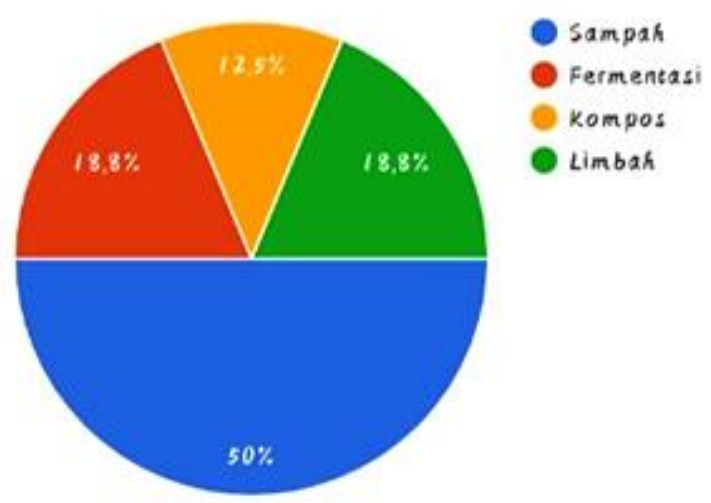

Gambar 8. Grafik pengetahuan tentang kompos

Dari Gambar 8 dapat dilihat bahwa $(18,8 \%)$ masyarakat mengetahui bahwa pelapukan bahan organik berupa sayuran ialah fermentasi, $(12,5 \%)$ masyarakat Koto Baru mengatakan bahwa pelapukan bahan organik berupa sayuran ialah kompos, (18,8\%) masyarakat Koto Baru mengatakan bahwa pelapukan bahan organik berupa sayuran ialah limbah, dan $(50 \%)$ masyarakat Koto Baru mengatakan proses pelapukan bahan organik berupa sayuran ialah sampah. 


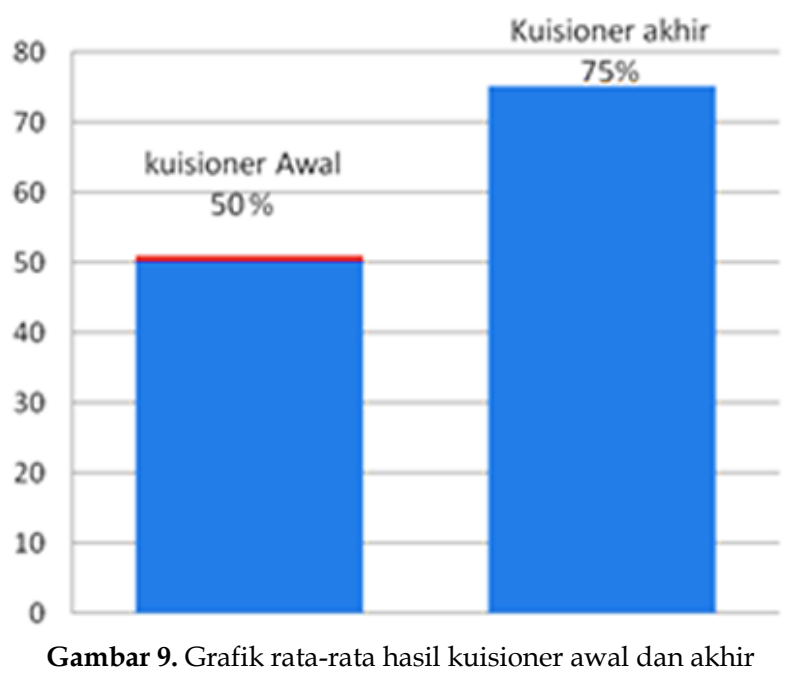

Dari Gambar 9 dapat dilihat bahwa terjadinya peningkatan pengetahuan masyarakat tentang pemanfaatan limbah sayur pasar Koto Baru menjadi pupuk organik, dimana sebelumnya pengetahuan masyarakat tentang pemanfaatan limbah (50\%) dan berubah menjadi (75\%) dari kuisioner akhir yang diberikan.

\section{KESIMPULAN}

Dari kegiatan pengabdian yang telah dilakukan dapat disimpulkan bahwa kegiatan sosialisasi pemanfaatan limbah sayur organik menjadi pupuk padat dan cair ramah lingkungan dilaksanakan secara daring melalui media sosial grub WhatsApp diikuti 15 orang ibu-ibu PKK berjalan lancar hingga selesai dan mendapatkan respon baik dari masyarakat sekitar, kemudian dapat memberikan edukasi tentang pentingnya kebersihan dan kesehatan lingkungan. Kegiatan pengabdian ini memberikan peningkatan pengetahuan kepada ibu-ibu PKK tentang pemanfaatan limbah sayur organik pasar Koto Baru menjadi POP dan POC ramah lingkungan dari 50\% menjadi 75\%, secara garis besar terjadinya peningkatan pengetahuan sebanyak 25\%. Dari kegiatan yang dilakukan, saran yang dapat diberikan ialah dengan mengelola dan memanfaatkan limbah sayur organik dan lakukan pengolahan limbah tersebut menjadi POP dan POC serta terjaganya kebersihan lingkungan.

\section{UCAPAN TERIMA KASIH}

Terima kasih kepada Simbelmawa Kemenristekdikti Republik Indonesia yang telah memberi dukungan finansial dengan nomor kontrak 1686/E2/TU/2020 sehingga terlaksanakan pengabdian ini.

\section{REFERENSI}

Anastasia, I., Izatti, M., Suedy, S.W.A. 2014. Pengaruh Pemberian Kombinasi Pupuk Organik Padat dan Organik Cair terhadap Porositas Tanah dan Pertumbuhan Tanaman Bayam (Amarantus Tricolor L.). Jurnal Akademika Biologi. 3(2):1-10

Bachtiar, B., Ahmad, A.H. 2019. Analisis Kandungan Hara Kompos Johar Cassia siamea Dengan Penambahan Aktivator Promi. Bioma : Jurnal Biologi Makassar. 4(1):68-76. https://doi.org/10.20956/bioma.v4i1.6493

Ghufron, M.A., Rozak, R.R., Fitrianingsih, A., Matin, M.F., Amin, A.K. 2017. Pelatihan Pengolahan Sampah Organik Menjadi Kompos Dengan Media Keranjang Takakura. J-ABDIPAMAS (Jurnal Pengabdian Kepada Masyarakat). 1(1):98-108. http://dx.doi.org/10.30734/j-abdipamas.v1i1.112 
Himawan, N., Kurniawan, D.H., Wahyuni, W., Hidayat, A.M., Supriati, Y., Fauziyyah, A., et al. 2018. Pemberdayaan Masyarakat Dalam Pengolahan Limbah Pertanian Menjadi Briket, Bokashi, Silase, Dan Kompos Cascing. Jurnal Pemberdayaan: Publikasi Hasil Pengabdian Kepada Masyarakat. 1(2):131-136. https://doi.org/10.12928/jp.v1i2.340

Indriyanti, D., Banowati, E., Margunani, M. 2015. Pengolahan Limbah Organik Sampah Pasar Menjadi Kompos. Jurnal Abdimas. 19(1):43-48

Mokodompis, D., Budiman, Balucu, E.P.H. 2018. Efektifitas Mikroorganisme Lokal MOL Limbah Sayuran dan Buah buahan sebagai Aktifator Pembuatan Kompos. Jurnal Kolaboratif Sains. 1(1):94-103. https://doi.org/10.31934/jom.v1i1.341

Muslimah. 2015. Dampak Pencemaran Tanah dan Langkah Pencegahan. Jurnal Penelitian Agrisamudra. 2(1):11-20. https://doi.org/10.33059/jpas.v2i1.224

Nur, T., Noor, A.R., Elma, M. 2016. Pembuatan Pupuk Organik Cair Dari Sampah Organik Rumah Tangga Dengan Penambahan Bioaktivator EM4 (Effective Microorganisms). Konversi. 5(2):44-51. http://dx.doi.org/10.20527/k.v5i2.4766

Rachman, F., Octalyani, E., Maulana, A., An-Najjah, I.S., Fauzan, N.D. 2021. H2 Super: Inovasi Pupuk Organik Cair dari Sampah Pasar H2, Desa Sido Mukti, Kecamatan Gedung Aji Baru. Altruis: Journal of Community Services. 2(1):4-7. https://doi.org/10.22219/altruis.v2i1.15962

Roidah, I.S. 2013. Manfaat Penggunaan Pupuk Organik Untuk Kesuburan Tanah. Bonorowo: Jurnal Universitas Tulungagung. 1(1):30-42. https://doi.org/10.36563/bonorowo.v1i1.5 